\title{
KONSEP DIRI REMAJA DARI KELUARGA BERCERAI
}

\author{
Lucy Pujasari Supratman \\ Fakultas Komunikasi dan Bisnis, Progam Studi Ilmu Komunikasi. Universitas Telkom. Jalan Telekomunikasi, \\ Dayeuhkolot, Bandung, 40257. Telp 02270020000. Kontak Pribadi 087722016384 \\ Email:me_gutschullerin@yahoo.com \\ Naskah diterima tanggal 6 Agustus 2015, direvisi tanggal 12 Oktober 2105, disetujui tanggal 30 Oktober 2015
}

\section{TEENAGERS SELF CONCEPT FROM DIVORCE FAMILY}

\begin{abstract}
Being an adolescent as a family member from parental divorce is still lacking to be appointed on a research topic, and mostly focused on the influence or impact of divorce. The researcher wants to explore adolescents' experiences from divorce families. The study was conducted using qualitative research methods through observation and in-depth interview with descriptive case study on ten adolescents from divorce families. While the respondents were taken by snowball sampling and purposive sampling. The results showed that adolescents have difficult experiences to be in divorce family. The adolescent experience of being displaced communicated verbally and nonverbally. The verbal communication is the language of motivation adolescents enlightened and openness. While the non verbal, they follow parents advices, full of comfort, and positive appearance. They become adolescents who have virtue in religiousity, independence, futuristic and maturity self-concept.
\end{abstract}

Keywords: self-concept, adolescent, divorcement.

\begin{abstract}
Abstrak
Remaja sebagai anggota keluarga yang ikut menjadi bagian dari perceraian masih minim untuk diangkat dalam penelitian-penelitian di bidang komunikasi antarpribadi. Penelitian tersebut lebih memfokuskan pada pengaruh serta dampak dari perceraian. Sedangkan tujuan penulis melakukan penelitian ini untuk menggambarkan pengalaman remaja dari keluarga bercerai. Penulis menggunakan metode penelitian kualitatif dengan pendekatan studi kasus deskriptif yang berjumlah sepuluh remaja dari keluarga bercerai. Mereka diambil secara purposive sampling. Teknik pengumpulan data memakai teknik observasi dan wawancara mendalam untuk menggali data dari informan. Hasil penelitian menunjukkan bahwa pengalaman remaja berada dalam keluarga bercerai adalah masa sulit. Pengalaman menjadi remaja terlantar dikomunikasikan secara verbal dan nonverbal. Komunikasi verbal remaja tercerahkan adalah bahasa motivatif dan keterbukaan. Sedangkan secara non verbal yaitu mengikuti nasihat, penuh kenyamanan, dan penampilan positif. Mereka menjadi remaja-remaja yang memiliki nilai kebaikan dalam konsep diri Religius, Independen, Futuristik dan Maturitas.
\end{abstract}

Katakunci: konsep diri, remaja, perceraian. 


\section{PENDAHULUAN}

Komunikasi dalam sebuah keluarga merupakan media penyampaian bagi orang tua untuk mengajarkan anak-anak tentang segala hal. Anak membutuhkan komunikasi agar mereka merasa disayang dan diperhatikan. Selain itu, perhatian orangtua melalui komunikasi menumbuhkembangkan semangat hidup untuk berjuang. Anak akan berkembang dengan penuh semangat serta memilki motivasi hidup. Djamarah (2004) menuturkan bahwa tanpa adanya komunikasi, sebuah kehidupan keluarga terasa hilang, karena di dalamnya tidak ada kegiatan berbicara, berdialog, bertukar pikiran, dan sebagainya, sehingga kerawanan hubungan antara orangtua dan anak sukar untuk dihindari. Oleh karena itu, komunikasi merupakan sesuatu yang esensial dalam kehidupan keluarga.

Bentukan keluarga pada orangtua yang memilih solusi perceraian untuk mengakhiri konflik tersebut mengalami perubahan hirarki. Keluarga baru terbentuk dengan hirarki sederhana. Hirarki tersebut terdiri dari ayah dan anak, atau ibu dan anak. Segrin (2005) mengistilahkan hirarki tersebut dengan terminologi keluarga dua inti (binuclear family). Binuclear family yaitu ayah atau ibu berubah menjadi orangtua tunggal (single parent). Setelah terjadi perceraian, bentuk keluarga awal mengalami perubahan karena remaja kehilangan salah satu anggota keluarga. Kedekatan fisik membuat proksimitas antara ayah ibu dan anak berubah. Anak mengalami kebingungan ketika harus memilih tinggal bersama antara ayah atau ibu.

Keluarga bercerai dapat membuat anak tidak mampu melakukan proses identifikasi pada orangtua. Proses tersebut adalah saat di mana ayah dan ibu tidak dapat berperan sebagai orangtua yang dapat dijadikan cermin berperilaku. Ketimpangan keberadaan orangtua yang menjalankan peran ganda sebagai ayah atau ibu tunggal hanya didapatkan dari salah satu pihak saja.

Ketimpangan peran sebetulnya dapat disikapi dengan perhatian dalam bentuk komunikasi. Pada kenyataannya, masih banyak orangtua yang meluputkan perhatian pada intensitas berkomunikasi dengan anakanak mereka. Kesibukan aktivitas mencari nafkah sekaligus mengurus keperluan rumah tangga menjadi kendala orangtua tunggal meluangkan waktu berkomunikasi dengan anak-anak. Komunikasi orangtua dan anakanak akan membuat mereka merasa bebas bercerita mengenai segala hal tanpa harus memendamnya sendiri. Saat mereka memendam perasaan-perasaan dalam diri yang ingin diungkapkan, dampak psikologis bagi anak yang orangtuanya bercerai dapat muncul, terutama bila kondisi anak dalam usia remaja.

Remaja berusia 12-25 tahun merasakan masa topan-badai yang mencerminkan kebudayaan modern yang penuh gejolak akibat pertentangan nilai karena perubahan perkembangan secara fisik, intelektual dan emosional. Santrock (2005) memaparkan bahwa masa remaja berakhir pada sekitar usia 18 hingga 22 tahun. Periode ini masa paling kritis bagi proses pencarian diri.

Remaja sebagai pribadi unik masih mencari konfigurasi minat, nilai, tujuan hidup dalam perbuatan keseharian. Mereka membutuhkan panutan yang dapat dijadikan suri tauladan menemukan pijakan prinsip hidup. Setiap perbuatan yang dilakukan kedua orangtua mencerminkan pola hidup yang mereka amati untuk dicontoh. Dalam pemahaman Erickson (1989), masa remaja masih berada dalam proses pencarian 'identitas diri'. Namun pada realitanya, mereka harus mengalami goncangan batin atas perceraian kedua orangtua mereka. Simanowitz (2003) menguraikan, "Adolescents can become obsessively concerned about how they appear to their peers, wanting to present the 'right' image but feeling that inside they are really someone different their outer façade. They wonder how to integrate earlier roles into their new sense of identity"

Konsep diri remaja dari keluarga bercerai menjadi ciri khas bagi penelitian penulis. Penelitian ini difokuskan pada konstruksi pengalaman komunikasi remaja 
dalam pemaknaannya terhadap pembentukan konsep diri. Analisis terhadap pengalaman individu akan memasukkan konsep interpretasi pada praktik kehidupan seharihari. Pendekatan ini mampu mengungkapkan kembali perasaan dan pemikiran dibalik pengalaman remaja dari keluarga bercerai saat mereka mengalami bentukan transformasi identitas yang baru. Berdasarkan latar belakang tersebut, rumusan masalah dalam penelitian ini yaitu bagaimana pemaknaan konsep diri remaja setelah perceraian kedua orangtua?; Bagaimana komunikasi antarpribadi remaja dengan ayah atau ibu setelah perceraian?. Tujuan penelitian ini adalah menemukan pemaknaan konsep diri remaja dari keluarga bercerai setelah mengalami perceraian kedua orangtua; Menggali komunikasi antarpribadi remaja dalam melakukan komunikasi antarpribadi dengan ayah atau ibu sebelum dan setelah perceraian kedua orangtua.

Kegunaan penelitian ini adalah diharapkan dapat memberikan kontribusi ilmiah terhadap bentuk komunikasi antarpribadi remaja dari keluarga bercerai. Pada tahap selanjutnya penelitian ini diharapkan dapat memperkaya khazanah komunikasi antarpribadi tentang komunikasi ayah-anak dan ibu-anak dari keluarga bercerai di masa kini, sehingga dapat menambah model-model komunikasi yang terus berkembang. Di tingkat praktis, penelitian ini diharapkan dapat menguak pengalaman remaja dan konstruksi konsep diri remaja dari keluarga bercerai. Di sisi lain, hasil penelitian ini diharapkan dapat menjadi refleksi bagi anak-anak dari keluarga bercerai yang mengalami peristiwa serupa.

\section{LANDASAN KONSEP}

\section{Teori Interaksi Simbolik George Herbert Mead}

Teori interaksi simbolik adalah interaksi yang memunculkan makna khusus dan menimbulkan interpretasi atau penafsiran. Simbolik berasal dari kata 'simbol' yakni tanda yang muncul dari hasil kesepakatan bersama. Bagaimana suatu hal menjadi perspektif bersama, bagaimana suatu tindakan memberi makna-makna khusus yang hanya dipahami oleh orang-orang yang melakukannya, bagaimana tindakan dan perspektif tersebut memengaruhi dan dipengaruhi subjek, semua dikaji oleh para penganut interaksinisme atau interaksionis simbolik.

(Mead, 1987) mengatakan ciri utama pembeda antara manusia dengan hewan adalah bahasa/simbol signifikan. Simbol signifikan haruslah merupakan suatu makna yang dimengerti bersama. Ia terdiri dari dua fase yaitu "me" dan "I". "Me" adalah sosok diri saya sebagaimana dilihat oleh orang lain, sedangkan "I" adalah bagian yang memerhatikan diri saya sendiri. Bagian penting dari pembahasan Mead adalah hubungan timbal balik antara diri sebagai objek dan diri sebagai subjek. Diri sebagai objek ditunjuk oleh Mead dengan konsep 'me', sementara sebagai subjek yang bertindak ditunjuknya dengan konsep "I". Analisis Mead mengenai "I" membuka peluang besar bagi kebebasan dan spontanitas.Ketika "I" memengaruhi "me", timbulah modifikasi konsep diri secara bertahap. Mead dalam bukunya Mind, Self and Society mengurai masing-masing gagasan dari Pikiran, Diri, dan Masyarakat. Penulis akan menjelaskan gagasan tersebut berdasarkan referensi dari Mead di bawah ini.

\section{Mind (Akal Budi atau Pikiran)}

Pikiran bagi Mead tidak dipandang sebagai objek, namun lebih pada proses sosial. Mead juga mendefinisikan pikiran sebagai kemampuan untuk menggunakan simbol yang memunyai makna sosial yang sama. Menurut Mead, manusia harus mengembangkan pikiran melalui interaksi dengan orang lain. Pikiran dalam analisis Mead adalah suatu proses internal individu yang menimbang-nimbang tentang kebaikankeburukan, keuntungan-kerugian sebuah tindakan sebelum individu melakukannya. Hal ini sangat dipengaruhi pengalamanpengalaman dan memori-memori masa lalu 
untuk sebuah pembelajaran.

Pada proses interaksi, secara umum akal pikiran manusia berorientasi pada rasionalitas. Melalui pikiran, manusia (aktor) bisa melakukan proses refleksi dengan penggunaan simbol-simbol saat berinteraksi. Simbol-simbol signifikan yang digunakan berbentuk simbol verbal dan nonverbal.

Simbol verbal dan nonverbal yang dimaknai setiap manusia tentu berbeda-beda. Hal ini disebabkan setiap manusia memiliki penafsiran sendiri atas refleksi dirinya pada sebuah fenomena. Seperti pikiran remaja yang memiliki kedua orangtua bercerai, mereka tidak serta merta memaknainya sebagai sebuah stigmatisasi negatif. Pengalaman remaja berada dalam kondisi mempunyai orangtua yang berpisah bisa jadi dipandang sebuah keputusan yang baik oleh pikiran mereka, dibandingkan bila remajaremaja tersebut harus terus ada di tengah konflik pertengkaran kedua orangtua. Hal ini mengakibatkan perbedaan makna yang kesemuanya tergantung pada pikiran tiap-tiap remaja dari keluarga cerai dalam memandang dirinya sendiri.

\section{Self (Diri)}

Diri menurut Mead (1987) juga bukan merupakan sebuah objek, namun sebagai subjek sebagaimana pikiran. Diri adalah kemampuan untuk merefleksikan diri sendiri dari perspektif orang lain. Bagi Mead, diri berkembang dari sebuah jenis pengambilan peran, membayangkan bagaimana kita dilihat oleh orang lain. Diri adalah suatu proses sosial yang memunyai kemampuan:

- Memberikan jawaban atau tanggapan kepada diri sendiri seperti orang lain memberi tanggapan atau jawaban,

- Memberikan jawaban atau tanggapan seperti norma umum memberikan jawaban kepadanya (Generalized others),

- Mengambil bagian dalam percakapannya sendiri dengan orang lain,

- Menyadari apa yang sedang dilakukannya sekarang dan kesadaran untuk melakukan tindakan pada tahap selanjutnya.
Menurut Mead, diri itu mengalami perkembangan melalui proses sosialisasi. Ada tiga tahap dalam proses sosialisasi ini, yaitu tahap bermain (Play Stage), tahap permainan (Game Stage), dan tahap orang lain pada umumnya (Generalized Others).Tahap bermain (Play Stage) penuh dengan kepurapuraan, maksudnya dalam tahap ini, anakanak mengambil peran atau mengandaikan dirinya sebagai orang lain. Atau "pura-pura menjadi orang lain". Dalam perkembangan yang "pura-pura" ini, proses pemahaman diri sebagai peran pengandaiannya kurang mapan, tidak tertata, dan tidak pada umumnya.

Diri menurut Mead adalah kemampuan khas manusia untuk menjadi subjek dan objek ( $I$ dan $M e$ ). Tiga tahap perkembangan diri manusia yang telah disebutkan di atas harus mengalami proses komunikasi antarmanusia, aktivitas, serta relasi sosial. I dalam analisis Mead menempatkan diri sebagai individu yang sangat subjektif. Oleh karena itu, $I$ akan memberikan reaksi yang berbeda-beda tiap individu akan suatu rangsangan atau stimulus. Nilai yang dianut oleh tiap individu menyebabkan beragamnya penafsiran dan intepretasi akan sesuatu. I juga membuat kehidupan baik individu dan sosial menjadi sangat dinamis. Pada taraf subjektivitas, perilaku individu akan menjadi spontan dan tidak teramalkan. Me lebih stabil daripada $I$, karena $M e$ adalah kristalisasi dari serangkaian norma yang dibuat secara umum. Artinya, diri sebagai objek akan memberi ruang untuk pengaruh norma sosial. Dengan kata lain, konsep generalized other akan sangat mempengaruhi diri. $M e$ membuat individu bertindak penuh dengan kontrol, sehingga setiap tindakannya akan normatif.

I merupakan proses pemikiran dan proses tindakan yang aktual, sedangkan me adalah proses reflektif. Jika me merupakan suatu sikap-sikap orang lain yang sudah diorganisasikan, maka $I$ merespons pada $m e$, dan me merefleksikan $I$ dalam suatu proses dialektika secara terus menerus. Karakter $I$ merupakan ketidakmenentuan yang relatif dan tidak dapat diramalkan. I merupakan langkah aktual yang diambil oleh seseorang dengan ketidakmenentuan di masa mendatang 
sehingga nantinya $I$ tidak dapat dihitung secara keseluruhan karena ia selalu terkait dengan spontanitas, perubahan, kebebasan dan inisiatif. Diri sebagai subjek adalah kemampuan diri untuk memberikan tanggapan terhadap apa yang ia keluarkan atau tujukan kepada orang lain. Tanggapan tersebut termasuk dalam serangkaian dari tindakan. Sedangkan diri sebagai objek adalah diri tidak hanya mendengarkan dirinya sendiri namun juga merespon tindakan yang telah dilakukan seperti respon dari individu lain.

\section{Society (Masyarakat)}

Fokus Mead adalah psikologi, maka tidak heran jika pembahasannya tentang masyarakat dapat dikatakan lemah. Menurut Mead (1987), masyarakat adalah sekedar organisasi sosial yang memunculkan pikiran dan diri yang dibentuk dari pola-pola interaksi antar individu. Analisis Mead tentang masyarakat, menggabungkan kajian fenomena mikro dan makro dari masyarakat. Mead mengatakan ada tiga unsur dalam masyarakat yaitu individu biologis, masyarakat mikro, dan masyarakat makro.

Pada awalnya, konsep individu biologis dimaknai oleh Mead sebagai individu yang polos dan belum mendapatkan pengaruh apaapa dari lingkungannya. Ketika individu itu mulai memasuki wilayah masyarakat yang mikro, maka individu itu akan terpengaruh dalam perilakunya. Masyarakat makro itu sendiri terbentuk dari serangkaian kompleks dari perilaku individu yang dipengaruhi oleh lingkungan mikro dari individu itu sendiri, seperti keluarga.

Konsep masyarakat mikro pada penelitian remaja ini adalah keluarga terdekat mereka yang telah menjadi significant other. Melalui keluarga, mereka mendapatkan nilainilai tentang kehidupan dan arti menjadi seorang manusia. Meskipun keluarga yang dimiliki remaja-remaja tersebut tidaklah sempurna, namun salah seorangtua mereka (single mother atau single father) menjadi pembelajaran diri mereka pada pembentukan konsep diri. Peran masyarakat mikro/keluarga sangat berperan penting bagi remaja, karena melalui komunikasi antarpribadi dengan single mother atau single father dapat membentuk perilaku individu biologis yang berbudi.

\section{METODE PENELITIAN}

\section{Studi Kasus Deskriptif}

Dalam studi kasus, metode terpenting tetap saja bersifat kualitatif. Menurut Faisal dalam Mulyana dan Solatun (2007), "Penelitian kualitatif malah harus membebaskan dirinya dari "tawanan" suatu teoriPencarian informan dilakukan penulis menggunakan teknik purposive sampling. Pemilihan informan didasarkan pada kriteria sebagai berikut:

1. Remaja akhir berusia 19-22 tahun

2. Berprofesi sebagai mahasiswa

3. Memiliki pengalaman orangtua bercerai saat informan masih berusia remaja

4. Memutuskan tinggal dengan ayah atau ibu atas kesadaran sendiri

5. Telah tinggal bersama ayah atau ibu selama 2-4 tahun setelah masa perceraian

\section{Profil Informan Remaja dari Keluarga Bercerai}

Jumlah informan yang terlibat berjumlah sepuluh orang remaja dari keluarga bercerai. Mereka adalah para mahasiswa dan mahasiswi yang berasal dari perguruan tinggi negeri dan swasta yang berada di kota Bandung. Teknik purposive sampling penulis lakukan pada kelas-kelas di mana para informan berada. Dari empat puluh dua mahasiswa di dalam kelas, enam remaja berasal dari keluarga bercerai. Namun, hanya tiga remaja saja yang sesuai dengan kriteria penelitian ini yaitu mengalami perceraian kedua orangtua di usia remaja. Sedangkan tiga remaja lainnya merasakan perceraian kedua orangtua saat masa kanak-kanak. Penelitian yang berfokus pada transformasi identitas remaja ini dipilih berdasarkan kriteria remaja akhir berusia 19-22 tahun, berprofesi sebagai mahasiswa, memiliki pengalaman orangtua bercerai saat informan 
Tabel 1

Profil Para Informan

\begin{tabular}{|c|c|c|c|c|c|c|}
\hline No & $\begin{array}{c}\text { Nama } \\
\text { Samaran } \\
\text { Remaja }\end{array}$ & $\begin{array}{l}\text { Usia Informan } \\
\text { Remaja } \\
\text { Sekarang }\end{array}$ & Prestasi & $\begin{array}{l}\text { Orangtua } \\
\text { Cerai } \\
\text { (Usia } \\
\text { Informan } \\
\text { Remaja) }\end{array}$ & Faktor Perceraian & $\begin{array}{c}\text { Setelah } \\
\text { Orangtua } \\
\text { Cerai Ikut }\end{array}$ \\
\hline 1 & Jati & 19 tahun & Gitaris Band Café & 15 tahun & $\begin{array}{l}\text { Tidak Memiliki } \\
\text { Tanggung Jawab }\end{array}$ & Ibu \\
\hline 2 & Pinus & 19 tahun & $\begin{array}{l}\text { Bassist Band Indie } \\
\text { 'Bang Your Head' }\end{array}$ & 16 tahun & Ekonomi & Ibu \\
\hline 3 & Palem & 19 tahun & $\begin{array}{c}\text { Marketing Motor } \\
\text { Yamaha }\end{array}$ & 15 tahun & $\begin{array}{c}\text { Ketidakharmonisan } \\
\text { Suasana keluarga } \\
\text { (suasana dingin) }\end{array}$ & Ayah \\
\hline 4 & Mahoni & 19 tahun & $\begin{array}{c}\text { Designer Baju di } \\
\text { Distro }\end{array}$ & 17 tahun & Perselingkuhan & Ibu \\
\hline 5 & Damar & 20 tahun & $\begin{array}{c}\text { Fotografer event } \\
\text { organizer }\end{array}$ & 16 tahun & Ekonomi & Ibu \\
\hline 6 & Mawar & 19 tahun & $\begin{array}{c}\text { SPG Produk } \\
\text { Makanan }\end{array}$ & 16 tahun & Perselingkuhan & Ibu \\
\hline 7 & Melati & 19 tahun & Juara Bakrie Award & 15 tahun & Ketidakharmonisan & Ibu \\
\hline 8 & Anggrek & 19 tahun & $\begin{array}{c}\text { Agen Pulsa Hand } \\
\text { phone }\end{array}$ & 17 tahun & Perselingkuhan & Ayah \\
\hline 9 & Kemuning & 19 tahun & $\begin{array}{l}\text { Pimred Buletin } \\
\text { kampus }\end{array}$ & 17 tahun & Ketidakharmonisa & Ibu \\
\hline 10 & Seroja & 19 tahun & $\begin{array}{c}\text { Raih Beasiswa } \\
\text { Yayasan }\end{array}$ & 17 tahun & Kekerasan & Ibu \\
\hline
\end{tabular}

Sumber: Hasil Penelitian (2015)

masih remaja, memutuskan tinggal dengan ayah atau ibu atas kesadaran sendiri dan telah tinggal bersama ayah atau ibu selama 2-4 tahun setelah masa perceraian. menelusuri remaja-remaja lainnya yang berasal dari keluarga bercerai berdasarkan kriteria informan. Profil informan terlihat pada tabel 1 (satu).

\section{HASIL PENELITIAN DAN PEMBAHASAN}

\section{Pemaknaan Konsep Diri Remaja Setelah Perceraian Orangtua}

Manusia merupakan makhluk dinamis yang terus belajar dari pengalamanpengalaman masa lalu sebagai bentuk pembelajaran baru. Mereka akan mengubah diri melalui pandangan-pandangan yang dianggap sesuai dengan konsep diri yang dianut. Perubahan pandangan tersebut tidak datang dengan sendirinya, melainkan membutuhkan mediator komunikasi untuk dapat merubah pandangan seorang individu. Mcguire dalam Fatoni (2014) menyatakan bahwa persepsi manusia selalu bersifat selektif karena keterbatasan pada indera. Realitas dikonstruksi secara selektif menurut tujuan, pengalaman masa lalu, simbol dan daya imajinasi seseorang.

Remaja-remaja dari keluarga bercerai mengubah pandangan pada konsep diri mereka setelah menjalani pengalaman perceraian kedua orangtua. Ketika remaja dikategorikan mengalami transformasi identitas (dari 'remaja tertelantarkan' menjadi 'remaja tercerahkan'), yang terjadi adalah perubahan kesadaran remaja tersebut yang tercerahkan. Transformasi identitas remaja tercerahkan melibatkan perubahan kesadaran dan sistem makna yang mengacu pada pengalaman masa lalu mereka serta komunikasi antarpribadi dengan significant others. 
Komunikasi antarpribadi merupakan proses pemberian dan penerimaan pesan antara dua atau diantara orang-orang dalam kelompok kecil melalui satu saluran atau lebih, dengan melibatkan umpan balik. Dalam penelitian ini, komunikasi antarpribadi dilihat pada berhasilnya hubungan pribadi antara remaja dan ibu tunggal/ayah tunggal membentuk konsep diri baru anak-anak remaja mereka.

Menurut hasil penelitian, komunikasi dari pembicaraan hati ke hati berguna untuk menemukan konsep diri remaja, membangun hubungan bermakna antara remaja-orangtua, serta mentransformasi nilai baru pada diri mereka. Keterampilan komunikasi antarpribadi remaja menggektifkan dimensi kualitas hubungan interpersonal. Bagi remaja, komunikasi antarpribadi yang mereka butuhkan adalah penguatan komunikasi dari sisi hubungan.

Komunikasi antarpribadi remaja menggunakan seluruh aspek dalam diri secara emosional. Pikiran dan perasaan menjadi satu kesatuan utuh untuk saling berinteraksi mendapatkan pengakuan. Pengakuan akan eksistensi penerimaan ditujukan dengan pendekatan personal dengan tujuan untuk merubah pandangan diri. Pandangan remaja mengalami perubahan setelah berkembangnya komunikasi antarpribadi yang efektif paska perceraian. Komunikasi dalam penelitian ini dapat melahirkan keterbukaan remaja pada orangtua untuk menciptakan rasa saling memotivasi yang berorientasi pada significant other.

Komunikasi interpersonal dalam kondisi keluarga yang penuh pertengkaran membuat remaja merasa tertekan berada di rumah. Mereka membutuhkan kehadiran seseorang untuk menjadi motivator remaja. Komunikasi yang terjalin setelah perceraian orangtua justru malah membantu terbentuknya komunikasi empatik significant others dari single mother atau single father untuk memberikan pemahaman positif bagi remaja. Tujuan komunikasi tersebut untuk membangun kembali konstruksi konsep positif dirinya. Konstruksi positif pada diri informan remaja ini membuat mereka dapat menerima keadaan perceraian kedua orangtua dengan pikiran positif dan tenang. Sikap dengan pikiran positif serta tenang adalah sikap yang mengurangi sikap defensif dalam komunikasi. Bersikap terbuka mendorong timbulnya saling pengertian, saling menghargai, dan yang paling penting yaitu saling mengembangkan kualitas hubungan interpersonal. Saat komunikasi orangtua dan anak bersifat dua arah, disertai dengan sikap positif, remaja akan mudah menerima nasehat atau arahan sehingga menimbulkan pengertian, dan hubungan orangtua-anak yang lebih berkualitas.

Dalam tahapan perkembangan remaja, Ball (2000) menyatakan bahwa masa remaja merupakan suatu fase hidup dimana individu-individu remaja tersebut sedang mencari dan membentuk konsep diri (selfconcept). Konsep diri informan remaja mengalami perubahan setelah perceraian kedua orangtua. Mereka yang pada awalnya memiliki konsep negatif tentang diri, kemudian bertransformasi menjadi diri yang konstruktif. Konsep diri tersebut penulis kategorisasikan menjadi empat konsep, yaitu: konsep diri religius, konsep diri independen, konsep diri futuristik, dan konsep diri maturitas.

\section{Konsep Diri Religius}

Masa remaja sarat dengan kelabilan dalam pencarian konsep diri ideal. Konsep diri seseorang terbentuk dengan sendirinya karena lingkungan terdekat dan pengalaman menjalani kehidupan. Pada masa ini, remaja menyadari kesadaran mendalam tentang kemampuan, potensi dan cita-cita diri. Kesadaran ini membawa aktualisasi diri dalam proses kehidupannya dengan mencari orang yang dapat dijadikan panutan.

Menurut hasil penelitian ini, panutan terdekat remaja yaitu orangtua. Namun bagi remaja yang orangtuanya bercerai, mereka akan memanut ayah atau ibu sesuai dengan pilihannya memilih untuk tinggal dengan siapa. Saat ayah/ibu single parent memiliki kadar agama yang baik, remaja akan mudah mengikuti anjuran, saran dan nasehat religiusitas. Aspek-aspek religi tersebut 
tentunya bergantung pada kepercayaan yang dipeluk masing-masing individu. Gambaran

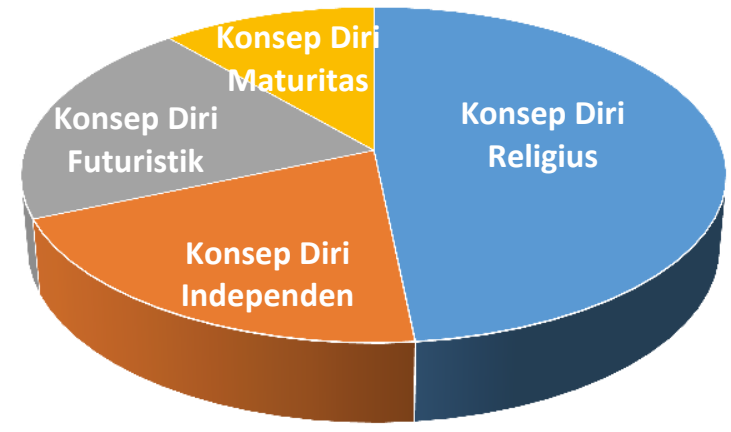

- Informan Mawar,

Kemuning, Seroja, Palem,

Pinus, Melati

- Informan Jati, Kemuning,

Mawar, Mahoni, Damar

- Informan Seroja, Kemuning,

Mahoni, Jati, Palem

Gambar 1

Makna Konsep Diri Remaja dari Keluarga Bercerai

Sumber: Hasil Penelitian (2015).

umum religiusitas adalah ketenangan batin, kedamaian jiwa dan keikhlasan hidup. Konsep diri remaja religius berdampak pada perkembanganmasa transisi rasa keagamaan menuju kedewasaan beragama sebagai pedoman hidup. Konsep ini membentuk pikiran remaja untuk menggabungkan kereligiusannya menghadapi kenyataan hidup yang mereka harus hadapi, serta menuntun mereka mendapatkan pemecahan masalah pribadi. Tentunya pencapaian perkembangan ini didukung oleh significant other (ayah/ibu) yang terlibat dalam pencarian konsep diri kereligiusitasan mereka.

\section{Konsep Diri Independen}

Konsep mandiri pada umumnya diterjemahkan menjadi kemampuan seseorang yang mantap menentukan sendiri tindakan dan keputusan sendiri dengan mempertanggungjawabkan seluruh perbuatannya. Individu semacam ini tidak mudah dipengaruhi orang lain karena ia memiliki kemantapan yang kokoh pada pemikiran. Remaja sebetulnya ingin dipandang menjadi manusia mandiri agar mereka diakui identitas indendensi. Mereka memiliki keinginan bebas yang dapat direalisasikan secara langsung melalui kapabilitas remaja tersebut.
Para informan remaja ini memiliki konsep diri independen melalui lima tahapan. Tahapan pertama adalah keberhasilan mereka berkomunikasi dengan significant other untuk memperoleh dukungan. Selanjutnya terciptalah anutan konsep diri berdasarkan figur sampel atau motivasional, lalu tercapai peran kemandirian sebagai remaja binangkit, kemudian menerima keadaan diri sebagai remaja dari keluarga bercerai, dan terakhir mengembangkan konsep diri independen untuk melakukan interaksi ekonomi di masyarakat. Mereka tahu bagaimana menyelesaikan masalah hidupnya sendiri. Independensi adalah bagian terpenting bagi pencarian konsep diri remaja. Bila seorang remaja telah berhasil menjadi mandiri, ia telah memiliki konsep diri yang baik.

\section{Konsep Diri Futuristik}

Remaja sebagai aset bangsa yang menyambungkan sejarah masa lalu dan impian masa depan hendaklah dipandang penting bagi kemajuan bangsa ini. Seluruh remaja (baik yang berasal dari keluarga harmonis dan bercerai) memegang tongkat estafet keberhasilan negara. Kehancuran sebuah negara dapat terjadi bila remaja penerus bangsa sudah tidak lagi memiliki 
konsep futuristik pada masing-masing dirinya.

Konsep futuristik tidak hanya dimiliki oleh remaja dari keluarga utuh. Pada penelitian ini, remaja-remaja yang orangtuanya bercerai memiliki konsep diri futuristik juga. Bahkan banyak dari mereka menargetkan cita-cita tinggi serta prestasi yang cukup membanggakan. Konsep diri futuristik mengarahkan pandangan remaja ke masa depan agar dapat berpacu untuk kehidupan positif. Mereka berani memiliki tujuan hidup dan cita-cita meski masih ada beberapa orang yang memandang remaja dari keluarga bercerai tidak memiliki masa depan cerah. Mereka berfikir visioner mencari jalan keluar di setiap masalah agar menjadi berharga sebagai remaja bagi keluarga.

\section{Konsep Diri Maturitas}

Menerima keputusan kedua orangtua untuk bercerai merupakan hal yang sulit dihadapi mayoritas anak-anak. Namun bila ia dapat menjadi dewasa (mature) menghadapi perpisahan ayah dan ibu, mereka tidak akan terjeremus pada hal-hal yang negatif. Kedewasaan mengambil sikap untuk tetap berada di jalan benar memerlukan pendampingan dari orang terdekat. Sebab tidak mungkin mereka dapat melalui masamasa sulit dimana pada akhirnya ayah dan ibu sudah tidak lagi bersama.

Kedewasaan bersikap ditauladani oleh mayoritas ibu mereka. Meski para ibu dalam keadaan terpuruk, mereka dapat mencontohkan kedewasaan bersikap menghadapi omongan miring masyarakat atas perceraian, beban ekonomi yang bertambah sebagai single parent dan mendidik anak-anak sendirian. Sikap dewasa tersebut muncul begitu saja akibat tempaan beban hidup yang mau tak mau harus dihadapi. Remaja memandang keberhasilan ibu menghadai problematika hidup sebagai tauladan yang positif. Mereka menyerap nilai-nilai maturitas tersebut sebagai konsep diri mereka setelah perceraian kedua orangtua. Menjadi remaja yang berpikiran dewasa tidak hanya dapat menentukan keputusan hidup yang terbaik untuk diri sendiri dan keluarga, tapi juga menjadi bijaksana menerima kelemahan diri sendiri untuk menjadi pelajaran kontemplasi menjadi diri yang lebih baik lagi.

\section{Komunikasi Antarpribadi Remaja Setelah Perceraian Orangtua}

Sebelum perceraian, remaja tidak memandapatkan perhatian penuh dari kedua orangtua. Pengalaman mereka sebagai remaja yang ditelantarkan dalam suasana ketegangan di rumah menjadikan mereka melampiaskan ketidaknyamanan diri dengan memberontak, lari dari rumah, berpenampilan buruk, berbahasa mengritik, abai, serta kaku. Transformasi diri remaja terjadi setelah fase perceraian kedua orangtua terlewati, penulis mengistilahkannya sebagai remaja tercerahkan. Represtasi secara nonverbal dan verbal dari remaja tercerahkan adalah ekspresi kesantunan, lebih mendekatkan diri, dan gerakan tubuh positif.

Para informan dalam penelitian ini semuanya memiliki dukungan dari significant other. Hal ini disebabkan transformasi diri di masa remaja terbangun berkat komunikasi efektif remaja dengan orangtua tunggal. Peranan orangtua bagi transormasi pengembangan diri mereka dapat membentuk sikap pada diri remaja. Penulis tidak melihat perbedaan pengalaman apakah remaja memilih ayah atau ibu. Saat pengadilan mengabsahkan perceraian, remaja dengan penuh sadar memutuskan untuk tinggal bersama ayah atau ibu. Remaja bebas menentukan kenyamanan yang ingin dia peroleh. Apalagi, remaja sudah mengalami pengalaman yang tidak menyenangkan sebelum perceraian terjadi di rumah. Pengalaman remaja sebelum perceraian dihadapkan pada permasalahan ketidak kondusifan atmosfir lingkungan rumah yang meruncing pada perceraian orangtua. Di usia ini remaja merasakan masa pergolakan yang dipenuhi konflik dan perubahan suasana hati. Tanpa adanya dukungan dari orangtua, remaja merefleksikan diri dengan komunikasi yang negatif.

Di masa remaja ini mereka belum menemukan siapa identitas diri mereka yang sebenarnya. Mereka senang dengan perilaku 
coba-coba atau perilaku mengidentifikasi orang untuk mencari identitasnya. Saat remaja mengalami kegagalan menemukan identitas diri, remaja akan mengalami sebuah krisis identitas. Ekspresi emosi yang belum labil dan perilaku tidak baik muncul dalam kehidupan pribadi sebagai remaja tertelantarkan. Karena kebingungan identitas inilah terbentuk konsep diri remaja yang tidak menggambarkan keadaan diri sebenarnya, melainkan sebagai bentuk komunikasi verbal dan non verbal remaja tertelantarkan untuk mengeskrepresikan suara mereka agar didengar orangtua. Significant other tidak bisa mengoptimalkan ketidakstabilan emosi remaja yang membutuhkan pengarahan bagi perkembangan pencarian identitas dirinya.

Mead dalam Mulyana (2010) menjelaskan bahwa diri tumbuh ketika individu mendapatkan pengalaman baru dan memberi makna kepada pengalaman karena diri itu bersifat dinamis. Pernyataan Mead tersebut menekankan 'diri' tidaklah bersifat statis, namun sangat berkembang. Saat remaja mengembangkan diri dengan cermin suri tauladan dari significant other yang dikomunikasikan baik oleh ayah atau ibu, diri mereka akan berkembang sehat melalui masamasa kebingungan identitas sebagai remaja tercerahkan.

Deskripsi tentang pengalaman remaja bangkit (remaja tercerahkan) dari pengalaman mereka sebelum kedua orangtua memutuskan untuk bercerai (remaja tertelantarkan) adalah pengejawantahan dari sikap menerima remaja pada keputusan orangtua bercerai. Remaja yang terlantar pada akhirnya dapat

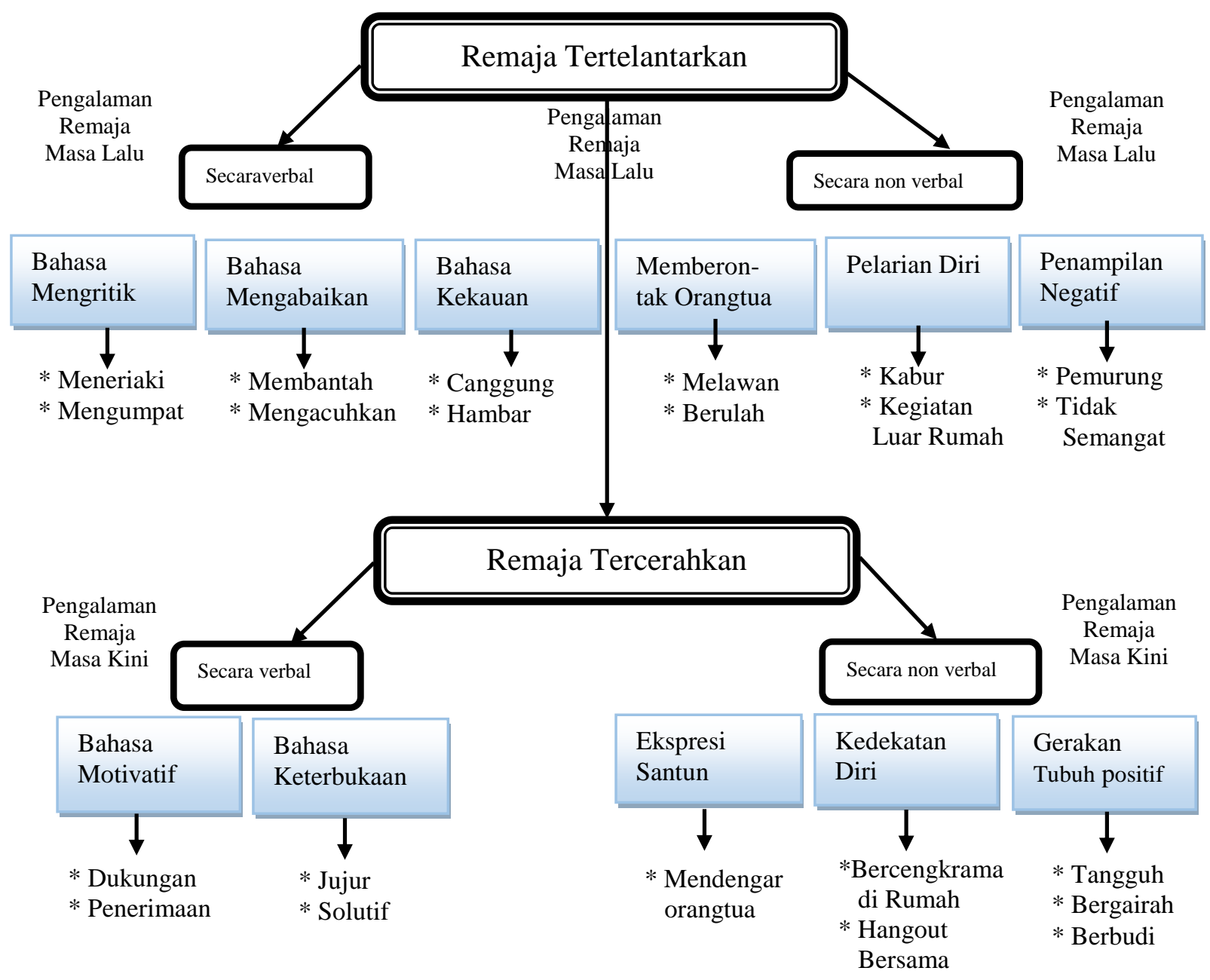

Gambar 2

Model Komunikasi Antarpribadi Remaja 
mentransformasikan diri berkat internalisasi dari pengalaman-pengalaman sebelum perceraian yang menginginkan rasa nyaman dari diri. Karakter remaja yang pemberontak, berhasrat melarikan diri dari lingkungan rumah, serta penilaian negatif pada diri sendiri tergulirkan dengan karaktertistik yang positif. Pengalaman remaja tertelantarkan ini menjadi sebuah hikmah bagi mereka dalam melihat masa depan yang lebih baik.

\section{PENUTUP}

\section{Simpulan}

Pemaknaan konsep diri remaja dari keluarga bercerai dibentuk melalui internalisasi diri remaja dalam komunikasi keluarga. Melalui komunikasi efektif, remaja dapat memiliki cermin tentang bagaimana harus bersikap melewati proses perceraian. Orangtua sebagai tauladan mengkomunikasikan nilai-nilai hidup positif untuk remaja kembangkan sendiri sesuai keinginannya. Sebab peran oragtua dalam penelitian ini hanya sebagai pembimbing saja. Remaja yang kemudian menginterpretasi diri mereka sendiri menjadi seseorang yang mereka inginkan berdasarkan bimbingan orangtua.

Relasi remaja yang terjalin dengan orangtua tunggal menjadi lebih personal. Interaksi remaja tersebut bertujuan untuk membentuk konsep diri yang berbeda setelah ayah dan ibu mereka memutuskan bercerai. Remaja menjadi aware tentang kondisi dirinya dan perlahan-lahan mulai menerima keadaan keluarga yang tidak utuh lagi. Pemaknaan mereka setelah perceraian terjadi adalah keinginan besar remaja dari keluarga bercerai untuk menunjukkan dirinya bahwa remaja tersebut dapat berhasil bangkit dari keterpurukan perceraian orangtua. Remaja juga tidak melakukan tindakan-tindakan yang merugikan diri. Justru mereka memaknai perceraian orangtua dengan menjadi remajaremaja yang memiliki nilai kebaikan dalam konsep diri Religius, Independen, Futuristik, Maturitas. Keempat konsep diri tersebut bermakna positif bagi remaja karena ayah/ibu single parent telah menanamkan nilai-nilai positif dalam dirinya pada anak mereka.

Keluarga merupakan tempat terdekat agar remaja mau terbuka dalam menghadapi masalah. Sebelum perceraian, remaja melakukan komunikasi ofensif frontal dan komunikasi ofensif lunak. Komunikasi ofensif frontal diungkapkan dengan melontarkan argumen seperti berteriak kasar, membantah perintah dan mengritik. Sedangkan komunikasi ofensif lunak diungkapkan dengan mengunci diri di kamar seperti mendengarkan musik lewat earphone, pura-pura tidur dan mengobrol di sosial media.

Keterbukaan komunikasi remaja dan orangtua dapat terjalin dengan baik setelah perceraian kedua orangtua melalui komunikasi empatik. Komunikasi empatik merupakan pengalaman berharga bagi transformasi diri remaja yang dahulu telah menyaksikan langsung pertengkaran orangtua. Remaja menjadi lebih terbuka menerima pengarahan dan nasehat untuk kebaikan diri remaja itu sendiri.

\section{Saran}

Setelah orangtua memutuskan berpisah, remaja tentu tetap ingin memiliki keinginan merasa diakui keberadaannya. Perpisahan bukan sebuah akhir dari sebuah hubungan bagi seorang anak, sebab tidak ada istilah mantan anak bagi orangtua. Maka tetaplah menjaga komunikasi yang baik dengan kedua belah pihak (ayah dan ibu) setelah perceraian terjadi. Apapun konflik yang terjadi antara ayah dan ibu, tidak akan mengubah pandangan remaja sebagai anak kandung yang tetap harus menghormati kedua orangtua.

Komunikasi yang diinisiasi oleh remaja sendiri akan mengubah pandangan orangtua bahwa perceraian tersebut dapat diterima, bilamana keputusan bercerai adalah yang terbaik bagi ayah dan ibu. Sebab, beberapa orangtua dalam penelitian ini merasa khawatir bila anaknya akan merasa menjadi korban perceraian. Remaja harus berusaha 
memahami keinginan orangtua yang sudah tidak dapat lagi bersama karena alasan-alasan perpisahan yang sudah sulit ditolelir. Keinginan orangtua berpisah akan merasa didukung bila remaja menerbukakan persetujuan tersebut pada kedua belah pihak.

\section{DAFTAR PUSTAKA}

\section{Buku:}

Ball, Stephen J., Maguire M M and Macrae S. (2000). Choices Pathways and Transitions, Post 16: New Youth, New Economies in the Global City. London: RoutledgeFalmer.

Djamarah, Syaiful Bahri. (2004). Pola Komunikasi Orang Tua dan Anak Dalam Keluarga. Jakarta: Rineka Cipta. Erikson, Erick, H. (1989). Identitas dan Siklus Hidup Manusia; Bunga Rampai 1. Terj Agus Cremers. Jakarta : PT. Gramedia.

Mead, George Herbert. (1987). Mind, Self and Society. London: The University Chicago Press.
Mulyana, Dedy. (2010). Metodologi Penelitian Kualitatif:Paradigma Baru Ilmu Komunikasi dan Ilmu Sosial lainnya. Bandung: Remaja Rosdakarya.

Santrock, John. W. (2005). Adolescence (terj). Jakarta: Erlangga.

Segrin, Chris, Flora, Jeanne. (2005). Family Communication. London: Lawrence Erlbraum Associates Publishers.

Simanowitz, Valerie dan Peter Pearce. (2003). Personality Development. London: Copyright Licensing Agency Ltd.

\section{Disertasi}

Fatoni, Uwes. 2014. Transformasi Identitas Ahmadi Setelah Keluar dari Ahmadiyah (Studi Fenomenologis tentang Perubahan Konsep Diri dan Pola Komunikasi Mantan Ahmadi di Tenjowaringin Tasikmalaya). Disertasi: Program Pascasarjana Unpad 